\title{
Hierarchical Ni2P@Ni(OH)2 Architectures \\ Supported On Carbon Cloth As Battery-Type Electrodes For Hybrid Supercapacitors With Boosting Specific Capacitance and Cycle Stability
}

\author{
Yingying Lan \\ Northwest University \\ Hongna Xing \\ Northwest University \\ Yan Zong \\ Northwest University \\ Yong Sun \\ Northwest University \\ Linxue Zhang \\ Northwest University \\ Yajing Wang \\ Northwest University \\ Xinghua Li \\ Northwest University \\ Xinliang Zheng ( $\nabla$ zhengxl@nwu.edu.cn ) \\ Northwest University https://orcid.org/0000-0003-3836-2982
}

\section{Research Article}

Keywords: Ni2P@Ni(OH)2 nanosheets, Battery-type electrodes, Hybrid supercapacitor, Energy storage

Posted Date: February 16th, 2021

DOI: https://doi.org/10.21203/rs.3.rs-194018/v1

License: (c) (1) This work is licensed under a Creative Commons Attribution 4.0 International License. Read Full License

Version of Record: A version of this preprint was published at Journal of Materials Science: Materials in Electronics on March 1st, 2021. See the published version at https://doi.org/10.1007/s10854-021-05521- 
1 Hierarchical $\mathrm{Ni}_{2} \mathbf{P} @ \mathrm{Ni}(\mathrm{OH})_{2}$ architectures supported on carbon cloth as battery-type electrodes for hybrid supercapacitors with boosting specific capacitance and cycle stability

4

$5 \quad$ Yingying Lan $^{1,2, \#}$, Hongna Xing, \#, Yan Zong ${ }^{1}$, Yong Sun ${ }^{1}$, Linxue Zhang ${ }^{1,3}$, Yajing

$6 \quad$ Wang $^{1}$, Xinghua $\mathrm{Li}^{1}$, Xinliang Zheng ${ }^{1, *}$

${ }^{1}$ School of Physics, Northwest University, Xi'an, Shaanxi 710127, China.

${ }^{2}$ Songshan Lake Materials Laboratory, Dongguan, Guangdong 523808, China

${ }^{3}$ School of Medical Engineering and Technology, Xinjiang Medical University, Urumqi, Xinjiang

11 830011, China.

${ }^{\#}$ These authors contribute equally to this work.

*Corresponding author: zhengxl@nwu.edu.cn (X. Zheng)

\section{Abstract}

In this work, a novel binder-free electrode, in which three-dimensional porous $\mathrm{Ni}_{2} \mathrm{P} @ \mathrm{Ni}(\mathrm{OH})_{2}$ nanosheet arrays were in-situ grown on carbon cloth $(\mathrm{CC})$, is rationally designed for supercapacitor applications. In comparison with $\mathrm{Ni}_{2} \mathrm{P} @ \mathrm{CC}$, the $\mathrm{Ni}_{2} \mathrm{P} @ \mathrm{Ni}(\mathrm{OH})_{2} @ \mathrm{CC}$ electrode represents superior electrochemical characteristics: the gravimetric capacitance and areal capacitance are boosted to be $632 \mathrm{C} \mathrm{g}^{-1}$ and $0.73 \mathrm{C}$

$21 \mathrm{~cm}^{-2}$ at $1 \mathrm{~mA} \mathrm{~cm}^{-2}$, about 2 and 2.7 times larger than those of $\mathrm{Ni}_{2} \mathrm{P} @ \mathrm{CC}\left(321 \mathrm{C} \mathrm{g}^{-1}\right.$ and $0.27 \mathrm{C} \mathrm{cm}^{-2}$ ), respectively; the rate capability is improved to be $63.3 \%$ from 1 to 
$110 \mathrm{~mA} \mathrm{~cm}^{-2}$, about 1.5 times larger than $\mathrm{Ni}_{2} \mathrm{P} @ \mathrm{CC}(42.9 \%)$; the cycle stability is

2 enhanced to be $81.4 \%$ after 1000 cycles, about 1.6 times larger than $\mathrm{Ni}_{2} \mathrm{P} / \mathrm{CC}(51.8 \%)$.

3 The assembly $\mathrm{Ni}_{2} \mathrm{P} @ \mathrm{Ni}(\mathrm{OH})_{2} @ \mathrm{CC} / / \mathrm{AC}$ hybrid supercapacitor device shows high

4 energy density of $23.5 \mathrm{Wh} \mathrm{kg}^{-1}$ at a power density of $1158.0 \mathrm{~W} \mathrm{~kg}^{-1}$ and good cycling

5 stability of $75.2 \%$ maintenance after 5000 cycles. Benefiting from the combined

6 advantages of high electronic conductivity and large specific capacitance of $\mathrm{Ni}_{2} \mathrm{P}$,

7 superior anion exchanging/intercalating capacity of $\mathrm{Ni}(\mathrm{OH})_{2}$, excellent flexibility of

8 carbon cloth and special hierarchical architecture with large surface area, the

$9 \mathrm{Ni}_{2} \mathrm{P} @ \mathrm{Ni}(\mathrm{OH})_{2} @ \mathrm{CC}$ electrode is promised to be a good candidate for 10 supercapacitors.

11 Keywords: $\mathrm{Ni}_{2} \mathrm{P} @ \mathrm{Ni}(\mathrm{OH})_{2}$ nanosheets; Battery-type electrodes; Hybrid 12 supercapacitor; Energy storage

\section{Introduction}

As the depletion of non-renewable fossil fuels and consequent environmental pollutions are ever-increasing serious, the exploration of clean and renewable energy sources, such as solar, wind, tide and geothermal has drawn growing concerns [1-4]. However, these energy sources are shackled by time or region, and the utilization efficiency is relative low [5-7]. Developing novel high-efficient energy storage and conversion systems are urgently demanded. Supercapacitors has attracted widespread attention, owing to their specific features such as higher power density than batteries, larger specific energy than conventional capacitors, reliable cycling stability, fast 
1 charge/discharge rates, safety, low cost and environmental friendliness [8-11].

2 However, the low energy density of supercapacitors limits its practical application

3 [12-14]. According to the energy storage mechanism, supercapacitors can be divided

4 into two types: electrical double-layer capacitors (EDLCs) and pseudocapacitor (PCs)

5 [15-18]. Generally, PCs possess larger energy storage ability than EDLCs, due to that

6 the electrode materials of PCs show rich oxidation states for faradaic redox reactions.

7 The core technology of PCs is exploring novel electrode materials with high specific

8 capacitance.

9 Recently, battery-type electrode materials, especially transition metal compounds, have been widely used for supercapacitors. This is owing to their efficient faradaic 11 redox reactions [19-21]. As a kind of n-type semiconductors, metal phosphides have two types of bonding states: the covalent bonded metal cations can store charges through faradaic redox reactions; the metal bonded atoms can improve the electrical conductivity through free electrons [22]. This specific structure makes metal 15 phosphides possess metalloid property and excellent electrical conductivity. electronegative, which can result in faster electron migration and superior redox activity [23]. These features are beneficial for electron transport that can improve the rate capability [24]. The transition metal phosphides (TMPs) have larger theoretical capacitance and higher electrical conductivity in comparison with the transition metal oxides (TMOs) [25]. Moreover, the nanostructures of TMPs are usually highly tunable for the access of electrolytes, leading to excellent intra- and inter-particle 
1 conductivity, which is also important for electrode materials [26]. These intrinsic

2 chemical/physical features make TMPs potential for supercapacitors. Wang et al.

3 prepared amorphous Ni-P nanomaterials by a solvothermal route, which show a large

4 specific capacitance of $1595 \mathrm{~F} \mathrm{~g} \mathrm{~g}^{-1}$ at $0.5 \mathrm{~A} \mathrm{~g}^{-1}$ and $71.4 \%$ capacitance preserved after

51000 cycles [27]. Lu et al. fabricated spherical and rod-like $\mathrm{Ni}_{2} \mathrm{P}$ nanostructures by

6 hydrothermal-phosphidation two-step process, and found that the rod-like $\mathrm{Ni}_{2} \mathrm{P}$

7 nanostructures have a larger specific capacitance of $799.2 \mathrm{~F} \mathrm{~g}^{-1}$ at $1 \mathrm{~A} \mathrm{~g}^{-1}$ and cycling

8 stability of $68.4 \%$ after 2500 cycles [28]. Obviously, the metal phosphides present

9 remarkable electrochemical performance, but their specific capacitance and cycle

10 stability still need to be further improved.

11 Generally, interface construction can introduce interfacial charge migration owing

12 to the generated strain at the interface, which is promised to be an effective way to

13 boost the electrochemical properties of electrode materials [29, 30]. Hierarchical

14 core-shell architectures are proposed to be a kind of hybrid nanostructures that can

15 enlarge the surface/interface area, improve the contact of electrode/electrolyte and

16 shorten the channel of ion diffusion [31-33]. Especially, properly constructing

17 core-shell architectures composited of core with large electrical conductivity and shell

18 with pseudo-capacitivity are promised to be of great significance for supercapacitors

$19[34,35]$. The particular heterostructure may induce internal electric fields and

20 discontinuous charges at the interface, which can enhance the electric/ionic

21 conductivity and improve the redox reaction kinetics. Besides, this core-shell

22 heterostructure can enhance the electron storage/delivery pathway, facilitate the redox 
1 reactions and improve the durability. Metal layered double hydroxides (LDHs) with

2 hydrotalcite-like structure and pseudo-capacitivity have drawn many attentions as

3 supercapacitors, due to their excellent anion exchanging capability and remarkable

4 intercalating ability [36-38]. Therefore, appropriately integrating metal phosphides

5 with hydroxides is promised to be a superior electrode material for supercapacitors,

6 which is expected to enhance the capacitance and improve the cycle stability.

7 Inspired by the aspects mentioned above, we fabricated hierarchical

$8 \mathrm{Ni}_{2} \mathrm{P} @ \mathrm{Ni}(\mathrm{OH})_{2}$ architecture grown on carbon cloth $(\mathrm{CC})$ through a combined

9 phosphorization and hydrothermal route. The $\mathrm{Ni}_{2} \mathrm{P} @ \mathrm{Ni}(\mathrm{OH})_{2} @ \mathrm{CC}$ is directly used as

10 a binder-free battery-type electrode for hybrid supercapacitors. In addition to the

11 synergistic effects of combined advantages for $\mathrm{Ni}_{2} \mathrm{P}$ and $\mathrm{Ni}(\mathrm{OH})_{2}$ as mentioned above,

12 the $\mathrm{Ni}_{2} \mathrm{P} @ \mathrm{Ni}(\mathrm{OH})_{2} @ \mathrm{CC}$ electrode is also promised to possess multiple advantages.

13 First, the $\mathrm{Ni}_{2} \mathrm{P} @ \mathrm{Ni}(\mathrm{OH})_{2}$ composites show three-dimensional hierarchical

14 architectures, in which both the $\mathrm{Ni}_{2} \mathrm{P}$ and $\mathrm{Ni}(\mathrm{OH})_{2}$ components show ultrathin

15 nanosheet structures. The special hierarchical structure is supposed to have large

16 surface area and rich electro-active sites, which make the contract between electrode

17 materials and electrolyte more sufficient. Second, as a cheap conductive textile,

18 carbon cloth is used as flexible substrate and current collector, which possesses

19 desirable features such as low cost, chemical stability, high conductivity and excellent

20 mechanical flexibility. Third, hierarchical $\mathrm{Ni}_{2} \mathrm{P} @ \mathrm{Ni}(\mathrm{OH})_{2}$ architectures were directly

21 grown on the flexible conductive carbon cloth substrate without using organic binders,

22 which can reduce the resistance between electrode materials and substrate, promoting 
1 the charge transfer. These benefits make the $\mathrm{Ni}_{2} \mathrm{P} @ \mathrm{Ni}(\mathrm{OH})_{2} @ \mathrm{CC}$ electrode a

2 promised candidate for supercapacitors.

\section{Experiment details}

4

\subsection{Reagents}

$\mathrm{NiCl}_{2} \cdot 6 \mathrm{H}_{2} \mathrm{O}$ was obtained from Tianjin kwangfu Fine Chemical Industry Research Institute. Tetramethothylamine (HMT), $\mathrm{NaH}_{2} \mathrm{PO}_{2} \cdot \mathrm{H}_{2} \mathrm{O}$ and potassium hydroxide $(\mathrm{KOH})$ were purchased from Sinopharm Chemical Reagents Co., Ltd., China. Before experiment, the carbon cloth $(\mathrm{CC})$ with a size of $1 \mathrm{~cm} \times 2 \mathrm{~cm}$ was successively cleaned by ultrasonication in ethanol and deionized water for each $30 \mathrm{~min}$, and finally dried at $60{ }^{\circ} \mathrm{C}$ for $8 \mathrm{~h}$ under vacuum conditions.

\subsection{Synthesis of hierarchical $\mathrm{Ni}(\mathrm{OH})_{2}$ nanoarray precursor on $\mathrm{CC}$}

$\mathrm{Ni}(\mathrm{OH})_{2}$ nanosheet arrays were directly grown on $\mathrm{CC}$ by a simple hydrothermal route. $\mathrm{NiCl}_{2} \cdot 6 \mathrm{H}_{2} \mathrm{O}(4 \mathrm{mmol})$ and HMT $(1.6 \mathrm{~g})$ were dissolved into de-ionized water $(60 \mathrm{ml})$ under magnetic stirring. Then, the above solution was poured into a Teflon-lined stainless-steel autoclave (100 mL), and several pieces of CC were immersed into the above solution. The autoclave was sealed and then heated at $100{ }^{\circ} \mathrm{C}$ for $6 \mathrm{~h}$ in an electric oven. After the reaction was finished, the $\mathrm{Ni}(\mathrm{OH})_{2} @ \mathrm{CC}$ electrode was rinsed with de-ionized water and ethanol, and dried at $60{ }^{\circ} \mathrm{C}$.

\subsection{Synthesis of hierarchical $\mathrm{Ni}_{2} \mathrm{P} @ \mathrm{CC}$}

$\mathrm{Ni}_{2} \mathrm{P} @ \mathrm{CC}$ was fabricated by phosphorization route using $\mathrm{Ni}(\mathrm{OH})_{2} @ \mathrm{CC}$ as precursor. Typically, the prepared $\mathrm{Ni}(\mathrm{OH})_{2} @ \mathrm{CC}$ and $\mathrm{NaH}_{2} \mathrm{PO}_{2} \cdot \mathrm{H}_{2} \mathrm{O}$ were put at two separated positions in a quartz boat with $\mathrm{NaH}_{2} \mathrm{PO}_{2} \cdot \mathrm{H}_{2} \mathrm{O}$ at the upstream side of the tube furnace. 
1 The tube furnace was heated to $300{ }^{\circ} \mathrm{C}$ with a heating rate of $2{ }^{\circ} \mathrm{C} / \mathrm{min}$ and kept at

$2300{ }^{\circ} \mathrm{C}$ for $2 \mathrm{~h}$. During all the processes, the furnace was protected in Ar atmosphere.

$3 \quad 2.4$ Synthesis of $\mathrm{Ni}_{2} \mathrm{P} @ \mathrm{Ni}(\mathrm{OH})_{2} @ \mathrm{CC}$

$4 \quad \mathrm{Ni}_{2} \mathrm{P} @ \mathrm{Ni}(\mathrm{OH})_{2} @ \mathrm{CC}$ was fabricated by a second hydrothermal route. The detailed

5 processes were consistent with the preparation method of $\mathrm{Ni}(\mathrm{OH})_{2} @ \mathrm{CC}$ precursor.

$6 \mathrm{Ni}_{2} \mathrm{P} @ \mathrm{CC}$ was immersed into the solution instead of $\mathrm{CC}$, which was used as the

7 substrate. Besides, the autoclave was kept at $100{ }^{\circ} \mathrm{C}$ for $90 \mathrm{~min}$.

8

\subsection{Characterization}

The structures of samples were determined by X-ray diffraction (XRD) using $\mathrm{Cu} \mathrm{K}_{\alpha}$ radiation (DX-2700, $\lambda=1.5418 \AA$ ) in the $2 \theta$ range of $10-80^{\circ}$ with a step size of $0.02^{\circ}$.

The morphologies were characterized by scanning electron microscopy (FESEM, Hitachi S-4800 microscope) and transmission electron microscopy TEM (FEI Tecnai $\mathrm{G}^{2}$ F20). The elemental compositions were tested by $\mathrm{X}$-ray photoelectron spectroscopy (XPS, ESCALAB210) and Energy dispersive spectroscopy (EDS) equipped in SEM. The Ni contents of active material were determined by inductively coupled plasma emission spectrometer (ICP-MS, 720-ES, VARIAN).

\subsection{Electrochemical measurements}

Electrochemical analyses were performed on a CHI 760E electrochemical workstation (Shanghai CH Instrument Company). Cyclic voltammetry (CV), galvanostatic charge-discharge (GCD) and electrochemical impedance spectroscopy (EIS) of the samples were carried out in a three-electrode setup using $6 \mathrm{M} \mathrm{KOH}$ aqueous solution as the electrolyte. The fabricated electrodes, standard calomel electrode (SCE) and Pt 
1 electrode were used as working electrode, reference electrode and counter electrode,

2 respectively.

3 The specific capacitance is calculated from the GCD curves according to the

4 following equations $[39,40]$ :

$5 \quad C_{m}=I \Delta t / m$

$6 \quad C_{s}=I \Delta t / s$

7 where $C_{m}$ is the gravimetric capacitance $\left(\mathrm{C} \mathrm{g} \mathrm{g}^{-1}\right), C_{s}$ is the areal capacitance $\left(\mathrm{C} \mathrm{cm}^{-2}\right), I$

8 is the discharge current (A), $\Delta t$ represents the discharging time (s), and $m$ and $s$

9 designate the mass of active material $(\mathrm{g})$ and geometrical area $\left(\mathrm{cm}^{2}\right)$, respectively.

\subsection{Assembly of the hybrid supercapacitor device}

11 The hybrid supercapacitor (HSC) was assembled using $\mathrm{Ni}_{2} \mathrm{P} @ \mathrm{Ni}(\mathrm{OH})_{2} @ \mathrm{CC}$ as the positive electrode and active carbon as the negative electrode. The HSC was packaged in a 2032-type button cell, in which a polypropylene membrane was used to separate the two electrodes. The negative electrode was fabricated by mixing activated carbon (AC), acetylene black and polytetrafluoroethylene (PTFE) with a weight ratio of 8: 1:

1. The forming slurry was painted on $\mathrm{CC}$ substrate and then dried at $60{ }^{\circ} \mathrm{C}$ in a vacuum oven for $12 \mathrm{~h}$. Generally, the positive and negative electrodes in the HSC device should satisfy charge balance principle $\left(\mathrm{q}^{+}=\mathrm{q}^{-}\right)$. The mass of AC can be

19 obtained by the following equations [21]:

$20 q=C_{m} \times m \times \Delta V$

$21 \quad \frac{m_{+}}{m_{-}}=\frac{C_{m}^{-} \times \Delta V^{-}}{C_{m}^{+} \times \Delta V^{+}}$

where $m$ is the weight of active material, $C_{m}$ is the specific capacity and $\Delta V$ is the 
1 potential window of electrode. The superscripts of ' + ' and '-' present the positive and

2 negative electrodes, respectively.

3 The energy density $(E)$ and power density $(P)$ can be calculated by the following

4 equations [41]:

$5 \quad E=I \int V(t) d t / m$

$6 \quad P=E / \Delta t$

\section{$7 \quad 3$ Results and discussions}

8 Fig. 1 shows the possible formation mechanism of hierarchical $\mathrm{Ni}_{2} \mathrm{P} @ \mathrm{Ni}(\mathrm{OH})_{2} @ \mathrm{CC}$

9 electrode. Firstly, the hierarchical $\mathrm{Ni}(\mathrm{OH})_{2}$ nanoarray precursor was in-situ grown on

flexible carbon cloth (CC) at a low temperature of $100{ }^{\circ} \mathrm{C}$ through a facile

hydrothermal method. Then, the $\mathrm{Ni}(\mathrm{OH})_{2} @ \mathrm{CC}$ precursor was treated at $300{ }^{\circ} \mathrm{C}$ by a phosphorization route using $\mathrm{NaH}_{2} \mathrm{PO}_{2} \cdot \mathrm{H}_{2} \mathrm{O}$ as the phosphorus source, forming

$\mathrm{Ni}_{2} \mathrm{P} @ \mathrm{CC}$. Finally, $\mathrm{Ni}_{2} \mathrm{P} @ \mathrm{CC}$ was treated by a secondary hydrothermal route, resulting in the formation of $\mathrm{Ni}_{2} \mathrm{P} @ \mathrm{Ni}(\mathrm{OH})_{2} @ \mathrm{CC}$ electrode. Fig. S1a shows the XRD pattern of $\mathrm{Ni}_{2} \mathrm{P} @ \mathrm{Ni}(\mathrm{OH})_{2} @ \mathrm{CC}$. Only the diffraction peaks of $\mathrm{Ni}_{2} \mathrm{P}$ (JCPDS: 74-1385) are obtained. The additional diffraction peak at about $26^{\circ}$ belongs to carbon (JCPDS: 38-0715) from the CC substrate. No diffraction peaks of $\mathrm{Ni}(\mathrm{OH})_{2}$ are found. This is mainly due to the combined effects of low crystallinity of hydroxides and tiny amount of $\mathrm{Ni}(\mathrm{OH})_{2}$ on the $\mathrm{CC}$ substrate (The mass loadings of $\mathrm{Ni}_{2} \mathrm{P}$ and $\mathrm{Ni}_{2} \mathrm{P} @ \mathrm{Ni}(\mathrm{OH})_{2}$ on CC substrate are 0.85 and $1.15 \mathrm{mg} \mathrm{cm}^{-2}$, respectively.). To further examine the crystalline phases of active materials in the electrodes, the corresponding nanopowders which were fabricated by the same process are also analyzed by XRD 
1 technology, as shown in Fig. S1b. The diffraction peaks of precursor (red line) can be

2 well indexed into $\alpha-\mathrm{Ni}(\mathrm{OH})_{2}$ with layered hydroxide structure. The broad diffraction

3 peaks suggest that the $\alpha-\mathrm{Ni}(\mathrm{OH})_{2}$ component has a low crystallinity. After

4 phosphorization treatment, the diffraction peaks (black line) can be assigned to $\mathrm{Ni}_{2} \mathrm{P}$

5 with hexagonal phase. The XRD patterns of nanopowders further demonstrate the

6 success of phosphorization treatment.

7 Fig. 2a shows the optical photographs of $\mathrm{CC}$ substrate, $\mathrm{Ni}(\mathrm{OH})_{2} @ \mathrm{CC}, \mathrm{Ni}_{2} \mathrm{P} @ \mathrm{CC}$

8 and $\mathrm{Ni}_{2} \mathrm{P} @ \mathrm{Ni}(\mathrm{OH})_{2} @ \mathrm{CC}$. Obviously, the color of the slices changes after each

9 preparation process, suggesting that the active materials were successfully in-situ

10 grown on the $\mathrm{CC}$ substrate as we desired. Optical photograph in Fig. 2b shows that

11 the $\mathrm{Ni}_{2} \mathrm{P} @ \mathrm{Ni}(\mathrm{OH})_{2} @ \mathrm{CC}$ electrode is flexible, which is of great significance for the

12 practical applications of supercapacitors. The morphologies and microstructures of the

13 electrodes were characterized by SEM and TEM. The CC substrate is weaved by

14 crossed carbon microfibers (Fig. S2). After in-situ growth, the active materials with

15 high density are densely packed on the microfibers of CC substrate (Fig. 2c and Fig.

16 S2b-c). From the high-magnification SEM image (Inset of Fig. 2c), the

$17 \mathrm{Ni}_{2} \mathrm{P} @ \mathrm{Ni}(\mathrm{OH})_{2}$ shows a three-dimensional (3D) hierarchical architecture which is

assembled by uninterrupted ultrathin nanosheets. The interconnected nanosheets of

$19 \mathrm{Ni}_{2} \mathrm{P}$ and $\mathrm{Ni}(\mathrm{OH})_{2}$ result in the formation of $3 \mathrm{D}$ network structure with multi-porous

surface, which is promised to provide high specific surface area and abundant open space. This unique structure can provide numerous electroactive sites and fast ionic diffusion pathway, which are beneficial for their electrochemical behaviors. EDS 
1 spectrum of $\mathrm{Ni}_{2} \mathrm{P} @ \mathrm{Ni}(\mathrm{OH})_{2} @ \mathrm{CC}$ (Fig. S3) contains $\mathrm{C}, \mathrm{O}, \mathrm{P}$ and Ni elements, which

2 is consistent with the XRD results. The EDS elemental mappings of

$3 \mathrm{Ni}_{2} \mathrm{P} @ \mathrm{Ni}(\mathrm{OH})_{2} @ \mathrm{CC}$ (Fig. 2d) further confirm that the $\mathrm{Ni}, \mathrm{P}$ and $\mathrm{O}$ elements are

4 uniformly distributed throughout the whole $\mathrm{CC}$ microfiber. Compared to the mapping

5 of $\mathrm{P}$ element, the mappings of $\mathrm{Ni}$ and $\mathrm{O}$ elements show relative larger distribution

6 areas, suggesting that $\mathrm{Ni}(\mathrm{OH})_{2}$ nanosheets successfully cover on the surface of $\mathrm{Ni}_{2} \mathrm{P}$

7 after the second hydrothermal route. ICP data (Table S1) reveals that the ratio of Ni

8 and $\mathrm{P}$ in $\mathrm{Ni}_{2} \mathrm{P} @ \mathrm{Ni}(\mathrm{OH})_{2} @ \mathrm{CC}$ is greater than 2:1, further confirming that the desired

9 phase has been successfully formed. For TEM characterization, the active materials

10 were scraped off from the $\mathrm{CC}$ substrate. Fig. 2e-f show the representative TEM

11 images of $\mathrm{Ni}_{2} \mathrm{P} @ \mathrm{Ni}(\mathrm{OH})_{2}$. HRTEM image in Fig. 2f shows interplanar spacing

12 distances of 0.204 and $0.233 \mathrm{~nm}$, corresponding to the (201) crystalline plane of $\mathrm{Ni}_{2} \mathrm{P}$

13 and (015) crystalline plane of $\mathrm{Ni}(\mathrm{OH})_{2}$, respectively.

14 The surface chemical constitutions and electronic states of $\mathrm{Ni}_{2} \mathrm{P} @ \mathrm{CC}$ and

$15 \mathrm{Ni}_{2} \mathrm{P} @ \mathrm{Ni}(\mathrm{OH})_{2} @ \mathrm{CC}$ electrodes were characterized by XPS. Full scan XPS spectrum

16 of $\mathrm{Ni}_{2} \mathrm{P} @ \mathrm{Ni}(\mathrm{OH})_{2} @ \mathrm{CC}$ (Fig. S4) indicates the existence of $\mathrm{C}, \mathrm{O}, \mathrm{Ni}$ and $\mathrm{P}$ elements

17 in the electrodes. Fig. 3a shows the high-resolution Ni 2p XPS spectra of $\mathrm{Ni}_{2} \mathrm{P} @ \mathrm{CC}$

18 and $\mathrm{Ni}_{2} \mathrm{P} @ \mathrm{Ni}(\mathrm{OH})_{2} @ \mathrm{CC}$ electrodes. For the $\mathrm{Ni}_{2} \mathrm{P} @ \mathrm{CC}$ (the down line in Fig. 3a), the

19 spectrum shows two spin-orbit doublets peaks at 857.6 and $875.2 \mathrm{eV}$, corresponding

20 to the $\mathrm{Ni} 2 \mathrm{p}_{3 / 2}$ and $\mathrm{Ni} 2 \mathrm{p}_{1 / 2}$ of $\mathrm{Ni}^{2+}$, respectively. Besides, two obvious shakeup peaks

21 at 862.5 and $880.6 \mathrm{eV}$ are related to the $\mathrm{Ni} 2 \mathrm{p}_{3 / 2}$ satellite and $\mathrm{Ni} 2 \mathrm{p}_{1 / 2}$ satellite,

22 respectively. The peaks at $853.0 \mathrm{eV}$ is probably attributed to the metallic Ni with 
1 binding energy of $852.6 \mathrm{eV}$, which is due to the partially charged $\mathrm{Ni}$ species $\left(\mathrm{Ni}^{\delta+}, \delta\right.$ is

2 closed to 0) [42]. The high-resolution XPS spectrum of Ni 2p of $\mathrm{Ni}_{2} \mathrm{P} @ \mathrm{Ni}(\mathrm{OH})_{2} @ \mathrm{CC}$

3 (top line in Fig. 3a) consists of two spin-orbit doublets characteristics accompanied by

4 two shakeup satellites. The doublet fitting peaks with binding energies at 857.1 and

$5 \quad 874.8 \mathrm{eV}$ correspond to the $\mathrm{Ni} 2 \mathrm{p}_{3 / 2}$ and $\mathrm{Ni} 2 \mathrm{p}_{1 / 2}$ of $\mathrm{Ni}^{2+}$, respectively. The other two

6 peaks are two plump shake-up satellite peaks (denoted as "Sat.") of $\mathrm{Ni}^{2+}$ [43].

7 Compared to $\mathrm{Ni}_{2} \mathrm{P} @ \mathrm{CC}$, the $\mathrm{Ni} 2 \mathrm{p}_{3 / 2}$ peak of $\mathrm{Ni}_{2} \mathrm{P} @ \mathrm{Ni}(\mathrm{OH})_{2} @ \mathrm{CC}$ shifts to lower

8 binding energy with a difference of $0.5 \mathrm{eV}$. High-resolution P 2p XPS spectra (Fig. 3b)

9 shows that the $\mathrm{P} 2 \mathrm{p}$ peaks in $\mathrm{Ni}_{2} \mathrm{P} @ \mathrm{CC}$ and $\mathrm{Ni}_{2} \mathrm{P} @ \mathrm{Ni}(\mathrm{OH})_{2} @ \mathrm{CC}$ are 134.7 and 133.6

$10 \mathrm{eV}$, respectively, corresponding to the typical of phosphate species, which is mainly

11 due to the partial superficial passivation of $\mathrm{P}$ species [44]. Obviously, the $\mathrm{P} 2 \mathrm{p}$ peak in $\mathrm{Ni}_{2} \mathrm{P} @ \mathrm{Ni}(\mathrm{OH})_{2} @ \mathrm{CC}$ also shifts to lower binding energy with a big difference of 1.1 $\mathrm{eV}$, which is probably due to the improved electron cloud density around the $\mathrm{P}$ atoms by the introduction of $\mathrm{Ni}(\mathrm{OH})_{2}$. These obvious shift phenomenons of $\mathrm{Ni} 2 \mathrm{p}$ and $\mathrm{P} 2 \mathrm{p}$ indicate the possible existence of strong electronic interactions and electron transfer at the interface between $\mathrm{Ni}_{2} \mathrm{P}$ and $\mathrm{Ni}(\mathrm{OH})_{2}$ [45]. The strong electronic interaction can generate internal electric fields, resulting in the improvement of electronic conductivity at the interfaces [34]. These results suggest that the in-situ growth of $\mathrm{Ni}(\mathrm{OH})_{2}$ may greatly affect the electrochemical performance of $\mathrm{Ni}_{2} \mathrm{P}$. sweep rate of $5 \mathrm{mV} \mathrm{s}^{-1}$. Fig. $4 \mathrm{~b}$ reveals the GCD curves of the two electrodes measured at a current density of $1 \mathrm{~mA} \mathrm{~cm}^{-2}$. The $\mathrm{CV}$ and GCD measurements for the 
1 two electrodes are carried out within a potential window from -0.2 to $0.6 \mathrm{~V}$. Both the

$2 \mathrm{Ni}_{2} \mathrm{P} @ \mathrm{CC}$ and $\mathrm{Ni}_{2} \mathrm{P} @ \mathrm{Ni}(\mathrm{OH})_{2} @ \mathrm{CC}$ electrodes exhibit broad redox reaction peaks

3 with noticeable faradaic current (Fig. 4a) and clearly potential platform (Fig. 4b),

4 indicating a representative battery-type pseudocapacitive feature [46, 47]. Obviously,

5 the covering area of $\mathrm{CV}$ curve and discharge time of GCD curve for the

$6 \mathrm{Ni}_{2} \mathrm{P} @ \mathrm{Ni}(\mathrm{OH})_{2} @ \mathrm{CC}$ electrode is far higher than those of $\mathrm{Ni}_{2} \mathrm{P} @ \mathrm{CC}$ electrode, which

7 directly indicates that the second growth of $\mathrm{Ni}(\mathrm{OH})_{2}$ can greatly increase the specific

8 capacitance and electrochemical performance of $\mathrm{Ni}_{2} \mathrm{P}$. Fig. $4 \mathrm{c}$ shows the typical $\mathrm{CV}$

9 curves of $\mathrm{Ni}_{2} \mathrm{P} @ \mathrm{Ni}(\mathrm{OH})_{2} @ \mathrm{CC}$ electrode measured at different sweep rates ranging from 5 to $50 \mathrm{mV} \mathrm{s}^{-1}$. Two distinct redox peaks can be observed, which are related to

11 the reversible electrochemical reactions of $\mathrm{Ni}^{2+}$ in the electrolyte. By increasing the

12 scanning rates from 5 to $50 \mathrm{mV} \mathrm{s}^{-1}$, the redox current increases gradually and the redox peaks shift to lower potential, which are mainly attributed to the charge diffusion polarization during the charging process [48, 49]. Fig. 4d reveals the GCD curves of $\mathrm{Ni}_{2} \mathrm{P} @ \mathrm{Ni}(\mathrm{OH})_{2} @ \mathrm{CC}$ electrode measured at various current densities ranging from 1 to $10 \mathrm{~mA} \mathrm{~cm}^{-2}$. All the GCD curves present clearly potential platform,

17 which further indicates the outstanding battery-type pseudocapacitive characteristics.

18 Compared with $\mathrm{Ni}_{2} \mathrm{P} @ \mathrm{CC}$ (Fig. S5), the GCD curves of $\mathrm{Ni}_{2} \mathrm{P} @ \mathrm{Ni}(\mathrm{OH})_{2} @ \mathrm{CC}$

19 electrode at different current densities show more symmetric potential-time shape,

20 suggesting that the $\mathrm{Ni}_{2} \mathrm{P} @ \mathrm{Ni}(\mathrm{OH})_{2} @ \mathrm{CC}$ electrode shows higher charge/discharge 21 coulombic efficiency with lower electric polarization. Fig. 4e shows the comparison 22 of areal capacitances and gravimetric capacitances between $\mathrm{Ni}_{2} \mathrm{P} @ \mathrm{CC}$ and 
$1 \mathrm{Ni}_{2} \mathrm{P} @ \mathrm{Ni}(\mathrm{OH})_{2} @ \mathrm{CC}$ electrodes at various current densities, which were calculated

2 from the GCD curves according to the equations (1) and (2). Noteworthy, compared

3 to $\mathrm{Ni}_{2} \mathrm{P} @ \mathrm{CC}$, the $\mathrm{Ni}_{2} \mathrm{P} @ \mathrm{Ni}(\mathrm{OH})_{2} @ \mathrm{CC}$ electrode has higher areal capacitances and

4 gravimetric capacitances in the whole current densities. At a low current density of 1

$5 \mathrm{~mA} \mathrm{~cm}{ }^{-2}$, the $\mathrm{Ni}_{2} \mathrm{P} @ \mathrm{Ni}(\mathrm{OH})_{2} @ \mathrm{CC}$ electrode has a gravimetric capacitance of $632 \mathrm{C}$

$6 \mathrm{~g}^{-1}$ and areal capacitance of $0.73 \mathrm{C} \mathrm{cm}^{-2}$, which are 2 and 2.7 times larger than those

7 of $\mathrm{Ni}_{2} \mathrm{P} @ \mathrm{CC}\left(321 \mathrm{C} \mathrm{g}^{-1}\right.$ and $\left.0.27 \mathrm{C} \mathrm{cm}^{-2}\right)$, respectively. At a high current density of 10

$8 \mathrm{~mA} \mathrm{~cm}{ }^{-2}$, the gravimetric capacitances of $\mathrm{Ni}_{2} \mathrm{P} @ \mathrm{Ni}(\mathrm{OH})_{2} @ \mathrm{CC}$ and $\mathrm{Ni}_{2} \mathrm{P} @ \mathrm{CC}$

9 electrodes are 400 and $138 \mathrm{C} \mathrm{g}^{-1}$, respectively. The $\mathrm{Ni}_{2} \mathrm{P} @ \mathrm{Ni}(\mathrm{OH})_{2} @ \mathrm{CC}$ electrode has

10 an improved rate capability of $63.3 \%$, while the rate capability of $\mathrm{Ni}_{2} \mathrm{P} @ \mathrm{CC}$ is only

$1142.9 \%$.

12 Electrochemical impedance spectra (EIS) is used to evaluate the ions migration rate

13 on the surface of electrodes, and the transport kinetics of charge diffusion, which is

14 carried out at an open circuit potential in the frequency ranging from $0.01 \mathrm{~Hz}$ to 100

$15 \mathrm{kHz}$. Fig. 4f shows the Nyquist impedance plot of $\mathrm{Ni}_{2} \mathrm{P} @ \mathrm{CC}$ and

$16 \mathrm{Ni}_{2} \mathrm{P} @ \mathrm{Ni}(\mathrm{OH})_{2} @ \mathrm{CC}$ electrodes. The real axis intercept at the high frequency range

17 represents ohmic series impedance $\left(\mathrm{R}_{\mathrm{s}}\right)$, which reflects the ionic resistance of

18 electrolyte, inherent resistances of electrodes and interface resistance [50]. And we

19 also use the $\mathrm{Rs}$ to reflect the conductivity of the materials $[51,52] . \mathrm{R}_{\mathrm{s}}$ of

$20 \mathrm{Ni}_{2} \mathrm{P} @ \mathrm{Ni}(\mathrm{OH})_{2} @ \mathrm{CC}$ electrode $(0.9168 \Omega)$ was decreased in comparison with that of

$21 \mathrm{Ni}_{2} \mathrm{P} @ \mathrm{CC}(1.077 \Omega)$. This suggests that $\mathrm{Ni}_{2} \mathrm{P} @ \mathrm{Ni}(\mathrm{OH})_{2} @ \mathrm{CC}$ has better electron

conductivity and excellent pathways for electron transport [45], which is desirable for 
1 high power density. The result is accordant with the CV and GCD results, which

2 indicates that $\mathrm{Ni}_{2} \mathrm{P} @ \mathrm{Ni}(\mathrm{OH})_{2} @ \mathrm{CC}$ has much better electrochemical performance than

$3 \mathrm{Ni}_{2} \mathrm{P} @ \mathrm{CC}$.

4 In order to investigate the charge storage mechanism of $\mathrm{Ni}_{2} \mathrm{P} @ \mathrm{CC}$ and

$5 \quad \mathrm{Ni}_{2} \mathrm{P} @ \mathrm{Ni}(\mathrm{OH})_{2} @ \mathrm{CC}$ electrodes, the corresponding $\mathrm{CV}$ results were further analyzed

6 (Fig. S6 and Fig. 4c). Generally, the relationship between measured current $(i)$ and

7 scan rate $(v)$ obeys the power law [53-56]:

$8 \quad i=a v^{b}$

9 where both $a$ and $b$ are constants. In the case of diffusion-controlled and surface capacitive processes, b value approaches 0.5 and 1 , respectively. Fig. 5 shows the

11 fitting results of $\mathrm{b}$ value using anodic peaks. The $\mathrm{b}$ values of $\mathrm{Ni}_{2} \mathrm{P} @ \mathrm{CC}$ and $\mathrm{Ni}_{2} \mathrm{P} @ \mathrm{Ni}(\mathrm{OH})_{2} @ \mathrm{CC}$ are calculated to be 0.50 and 0.62 , respectively. This result suggests that diffusion process is the major factors that determine the electrochemical properties of $\mathrm{Ni}_{2} \mathrm{P}$ and $\mathrm{Ni}_{2} \mathrm{P} @ \mathrm{Ni}(\mathrm{OH})_{2}$. Compared to $\mathrm{Ni}_{2} \mathrm{P}$, the introduction of $\mathrm{Ni}(\mathrm{OH})_{2}$ can improve the surface capacitive ability of $\mathrm{Ni}_{2} \mathrm{P} @ \mathrm{Ni}(\mathrm{OH})_{2}$. shown in Fig. 6. The capacitive retention of $\mathrm{Ni}_{2} \mathrm{P} @ \mathrm{Ni}(\mathrm{OH})_{2} @ \mathrm{CC}$ electrode was approximately $81.4 \%$ after 1000 charge/discharge cycles at a constant current density of $2 \mathrm{~mA} \mathrm{~cm}{ }^{-2}$, much higher than that of $\mathrm{Ni}_{2} \mathrm{P} @ \mathrm{CC}$ (51.8\%). Compared to $\mathrm{Ni}_{2} \mathrm{P} @ \mathrm{CC}$ electrode, the capacitive retention of the $\mathrm{Ni}_{2} \mathrm{P} @ \mathrm{Ni}(\mathrm{OH})_{2} @ \mathrm{CC}$ electrode increases in the early cycles and keeps unchanged, indicating that this electrode material has a good cycling stability. The initial increase in specific capacity could be ascribed to the 
1 infiltration and activation of $\mathrm{Ni}_{2} \mathrm{P} @ \mathrm{Ni}(\mathrm{OH})_{2} @ \mathrm{CC}$ electrode, which is also present in

2 other phosphide materials [57]. Besides, the $\mathrm{Ni}_{2} \mathrm{P} @ \mathrm{Ni}(\mathrm{OH})_{2} @ \mathrm{CC}$ electrode exhibits

3 over $95 \%$ of coulombic efficiency after 1000 charge-discharge cycles, demonstrating

4 good stability (Fig. S7). And the SEM image of $\mathrm{Ni}_{2} \mathrm{P} @ \mathrm{Ni}(\mathrm{OH})_{2} @ \mathrm{CC}$ electrode after

5 electrochemical testing is shown in the Fig. S8. Its morphology can still maintain the

6 multistage nanosheets structure, indicating that the electrode material has good

7 structural stability. The good cycling stability is mainly due to the unique

8 three-dimensional hierarchical architecture with self-assembled uninterrupted

9 ultrathin nanosheets on the surface of the material.

10 To further investigate the potential applications of the electrode, a hybrid

11 supercapacitors (HSC) device was assembled by employing $\mathrm{Ni}_{2} \mathrm{P} @ \mathrm{Ni}(\mathrm{OH})_{2} @ \mathrm{CC}$ as

12 the anode and AC as the cathode. To satisfy the charge balance, the mass of AC was

13 calculated using the equations (3) and (4). Fig. 7a reveals the CV curves of the HSC

14 device measured at different scan rates, which show a potential window of 0-1.6 V.

15 GCD curves of the HSC device are displayed in Fig. 7b. A clearly potential platform

16 can be seen in all the GCD curves measured at different current densities, suggesting

17 that the device should possess both electrical double-layer capacity and battery-like

18 capacity. Fig. 7c shows the corresponding specific capacitances obtained from Fig. $7 \mathrm{~b}$.

19 The specific capacitances are 247.4 and $119.8 \mathrm{mC} \mathrm{cm}^{-2}$ at 1 and $10 \mathrm{~mA} \mathrm{~cm}$,

20 respectively. The energy density and power density of the $\mathrm{Ni}_{2} \mathrm{P} @ \mathrm{Ni}(\mathrm{OH})_{2} @ \mathrm{CC} / / \mathrm{AC}$

21 HSC device were calculated by the equations (5) and (6). Fig. 7d shows the Ragone

22 plots of energy densities and power densities obtained from the GCD curves. The 
1 maximum energy density reaches $23.5 \mathrm{Wh} \mathrm{kg}^{-1}$ at a power density of $1158.0 \mathrm{~W} \mathrm{~kg}^{-1}$,

2 and remains $12.5 \mathrm{Wh} \mathrm{kg}^{-1}$ at $3756.3 \mathrm{~W} \mathrm{~kg}^{-1}$. Table $\mathrm{S} 2$ shows the comparison of energy

3 densities and power densities of $\mathrm{Ni}_{2} \mathrm{P} @ \mathrm{Ni}(\mathrm{OH})_{2} @ \mathrm{CC} / / \mathrm{AC}$ device with other Ni-based

4 phosphides HSC devices. Obviously, the $\mathrm{Ni}_{2} \mathrm{P} @ \mathrm{Ni}(\mathrm{OH})_{2} @ \mathrm{CC} / / \mathrm{AC}$ device represents

5 comparable or even better energy densities. Fig. 7e displays the cycling stability

6 performance of $\mathrm{Ni}_{2} \mathrm{P} @ \mathrm{Ni}(\mathrm{OH})_{2} @ \mathrm{CC} / / \mathrm{AC}$ HSC device. The charge/discharge cycles

7 were operated at $5 \mathrm{~mA} \mathrm{~cm}{ }^{-2}$ for 5000 cycles. The $\mathrm{Ni}_{2} \mathrm{P} @ \mathrm{Ni}(\mathrm{OH})_{2} @ \mathrm{CC} / / \mathrm{AC} \mathrm{HSC}$

8 device reveal good cycling stability, which possesses $75.2 \%$ maintenance after 5000

9 cycles.

\section{Conclusions}

11 In summary, three-dimensional hierarchical $\mathrm{Ni}_{2} \mathrm{P} @ \mathrm{Ni}(\mathrm{OH})_{2}$ architecture was in-situ 12 grown on a flexible carbon cloth substrate, which was used as a novel binder-free hybrid-type electrode for supercapacitor applications. Taking the combined benefits of high electronic conductivity of $\mathrm{N}_{2} \mathrm{P}$, superior anion exchanging/intercalating capacity of $\mathrm{Ni}(\mathrm{OH})_{2}$, special 3D porous hierarchical architectures and excellent flexibility of carbon cloth, the $\mathrm{Ni}_{2} \mathrm{P} @ \mathrm{Ni}(\mathrm{OH})_{2} @ \mathrm{CC}$ electrode shows boosting specific capacitance, rate capability and charge/discharge cycle stability in comparison with $\mathrm{Ni}_{2} \mathrm{P} @ \mathrm{CC}$. Charge storage mechanism investigations show that the introduction of $\mathrm{Ni}(\mathrm{OH})_{2}$ can improve the surface capacitive ability of $\mathrm{Ni}_{2} \mathrm{P}$. The assemble $\mathrm{Ni}_{2} \mathrm{P} @ \mathrm{Ni}(\mathrm{OH})_{2} @ \mathrm{CC} / / \mathrm{AC}$ hybrid supercapacitor device shows high energy density and good cycling stability. This study demonstrates that the three-dimensional hierarchical $\mathrm{Ni}_{2} \mathrm{P} @ \mathrm{Ni}(\mathrm{OH})_{2} @ \mathrm{CC}$ architecture with advanced synergistic effects holds 
1 great promise as hybrid electrode for supercapacitors.

\section{Acknowledgements}

3 This work was supported by the National Natural Science Foundation of China

4 (51572218), Natural Science Foundation of Shaanxi Province (2017KCT-01,

5 2019JM-138), Scientific Research Program Funded by Shaanxi Provincial Education

6 Department (18JK0786), Young Talent Fund of University Association for Science

7 and Technology in Shaanxi (20170605) and Key Project of Research and

8 Development of Shaanxi Province (2018ZDCXL-GY-08-05).

9 Compliance with ethical standards

10 Conflict of interest The authors declare no conflicts of interest.

11 References

1. J.T. Zhang, X.S. Zhao, On the configuration of supercapacitors for maximizing electrochemical performance. ChemSusChem 5, 818-841 (2012).

2. X.R. Li, J.L. Wei, Q. Li, S.S. Zheng, Y.X. Xu, P. Du, C.Y. Chen, J.J. Zhao, H.G.

4. X.R. Li, X.C. Yang, H.G. Xue, H. Pang, Q. Xu, Metal-organic frameworks as a platform for clean energy applications. EnergyChem. 2, 100027 (2020). 
1 5. X.Z. Yu, B.A. Lu, Z. Xu, Super Long-life supercapacitors based on the construction

2 of nanohoneycomb-like strongly coupled $\mathrm{CoMoO}_{4}-3 \mathrm{D}$ graphene hybrid electrodes.

3 Adv. Mater. 26, 1044-1051 (2014).

4 6. P. Poizot, F. Dolhem, Clean energy new deal for a sustainable world: from non- $\mathrm{CO}_{2}$

5 generating energy sources to greener electrochemical storage devices. Energy

$6 \quad$ Environ. Sci. 4, 2003 (2011).

7 7. B.W. He, P.Y. Kuang, X.H. Li, H. Chen, J.G. Yu, K. Fan, In situ transformation of

8. G.P. Wang, L. Zhang, J.J. Zhang, A review of electrode materials for

9. C. Peng, S.W. Zhang, X.H. Zhou, G.Z. Chen, Unequalisation of electrode capacitances for enhanced energy capacity in asymmetrical supercapacitors. Energy Environ. Sci. 3, 1499-1502 (2010).

10. G.Q. Zhang, H.B. Wu, H.E. Hoster, M.B. Chan-Park, X.W. (David) Lou, Single-crystalline $\mathrm{NiCo}_{2} \mathrm{O}_{4}$ nanoneedle arrays grown on conductive substrates as binder-free electrodes for high-performance supercapacitors. Energy Environ. Sci. 5, 9453-9456 (2012).

11. J.R. Miller, P. Simon, Electrochemical capacitors for energy management. Science 321, 651-652 (2008).

12. W. Zhou, K. Yu, D. Wang, J. Chu, J. Li, L. Zhao, C. Ding, Y. Du, X. Jia, H. Wang, G. Wen, Hierarchically constructed $\mathrm{NiCo}_{2} \mathrm{~S}_{4} @ \mathrm{Ni}_{(1-\mathrm{x})} \mathrm{Co}_{\mathrm{x}}(\mathrm{OH})_{2}$ core/shell 

(2016).

13. S. Peng, L. Li, H. B. Wu, S. Madhavi, X. W. (David) Lou, Controlled growth of $\mathrm{NiMoO}_{4}$ nanosheet and nanorod arrays on various conductive substrates as advanced electrodes for asymmetric supercapacitors. Adv. Energy Mater. 5, 1401172 (2015).

14. T. Liu, L.Y. Zhang, W. You, J.G. Yu, Core-shell nitrogen-doped carbon hollow spheres $/ \mathrm{Co}_{3} \mathrm{O}_{4}$ nanosheets as advanced electrode for high-performance supercapacitor. Small 14, 1702407 (2018).

15. Y. Zhong, X. Xia, F. Shi, J. Zhan, J. Tu, H.J. Fan, Transition metal carbides and nitrides in energy storage and conversion. Adv. Sci. 3, 1500286 (2016).

16. E. Frackowiak, Carbon materials for supercapacitor application, Phys. Chem. Chem. Phys. 9, 1774-1785 (2007).

17. Y. Wang, Y. Xia, Recent progress in supercapacitors: from materials design to system construction. Adv. Mater. 25, 5336-5342 (2013).

18. P. Simon, Y. Gogotsi, Materials for electrochemical capacitors. Nat. Mater. 7, 845-854 (2008).

19. Y.Z. Hu, C.H. Huang, S.P Jiang, Y.L. Qin, H. Chen, Hierarchical nickel-cobalt selenide nanoparticles/nanosheets as advanced electroactive battery materials for hybrid supercapacitors. J. Colloid Interface Sci. 558, 291-300 (2020).

20. W.L. Hong, L.Y. Lin, Design of nickel cobalt oxide and nickel cobalt oxide@nickel molybdenum oxide battery-type materials for flexible solid-state 
battery supercapacitor hybrids. J. Power Sources 435, 226797 (2019).

21. Y.M. Hu, M.C. Liu, Y.X. Hu, Q.Q. Yang, L.B. Kong, L. Kang, One-pot hydrothermal synthesis of porous nickel cobalt phosphides with high conductivity for advanced energy conversion and storage. Electrochim. Acta 215, 114-125 (2016).

22. J. Wen, S.Z. Li, T. Chen, B. Li, L.B. Xiong, Y.X. Guo, G.J. Fang, Porous nanosheet network architecture of $\mathrm{CoP} @ \mathrm{Ni}(\mathrm{OH})_{2}$ composites for high performance supercapacitors. Electrochim. Acta 258, 266-273 (2017)

23. X. Li, H. Wu, A.M. Elshahawy, L. Wang, S.J. Pennycook, C. Guan, J. Wang, Cactus-like NiCoP/NiCo-OH 3D architecture with tunable composition for high-performance electrochemical capacitors. Adv. Funct. Mater. 28, 1800036 (2018).

24. S. Wang, Z. Xiao, S. Zhai, G. Wang, Q. An, D. Yang, A high-temperature

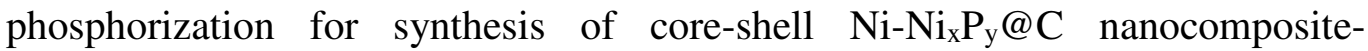
immobilized sponge-like P-doped porous carbon with excellent supercapacitance performance. Electrochim. Acta 309, 197-208 (2019).

25. Y. Xu, S. Hou, G. Yang, X. Wang, T. Lu, L. Pan, Synthesis of bimetallic $\mathrm{Ni}_{\mathrm{x}} \mathrm{Co}_{1-\mathrm{x}} \mathrm{P}$ hollow nanocages from metal-organic frameworks for high performance hybrid supercapacitors. Electrochim. Acta 285, 192-201 (2018).

26. X. Li, A. MElshahawy, C. Guan, J. Wang, Metal phosphides and phosphates-based electrodes for electrochemical supercapacitors. Small 13, 1701530 (2017).

27. D. Wang, L.B. Kong, M.C. Liu, W.B. Zhang, Y.C. Luo, L. Kang, Amorphous Ni-P 
materials for high performance pseudocapacitors. J. Power Sources 274, 1107-1113 (2015).

28. H. Wu, Y.H. Ni, M.F. Wang, D.C. Lu, Shape-controlled synthesis and performance comparison of $\mathrm{Ni}_{2} \mathrm{P}$ nanostructures. CrystEngComm 18, 5155-5163 (2016).

29. J.L. Xing, J. Du, X. Zhang, Y.B. Shao, T. Zhang, C.L. Xu, A Ni-P@ NiCo LDH core-shell nanorod-decorated nickel foam with enhanced areal specific capacitance for high-performance supercapacitors. Dalton Trans. 46, 10064 (2017).

30. Y. Cheng, Y.F. Zhang, H.M. Jiang, X.Y. Dong, J.Q. Zheng, C.G. Meng, Synthesis of amorphous cobalt silicate nanobelts@manganese silicate core-shell structures as enhanced electrode for high-performance hybrid supercapacitors. J. Colloid Interface Sci. 561, 762-771 (2020).

31. M. Racik K, A. Manikandan, M. Mahendiran, J. Madhavana, M.V. Antony Raj, M.G. Mohamed, T. Maiyalagan, Hydrothermal synthesis and characterization studies of $\alpha-\mathrm{Fe}_{2} \mathrm{O}_{3} / \mathrm{MnO}_{2}$ nanocomposites for energy storage supercapacitor application. Ceram. Int. 46, 6222-6233 (2020).

32. Y.H. Tian, L.Y. Lin, M.L. Ning, S. Hussain, H. Su, M.S. Javed, H.J. Zhen, N. Hu, A. Shaheen, Novel binder-free electrode of $\mathrm{NiCo}_{2} \mathrm{O}_{4} @ \mathrm{NiMn}_{2} \mathrm{O}_{4}$ core-shell arrays modified carbon fabric for enhanced electrochemical properties. Ceram. Int. 45, 16904-16910 (2019).

33. T.F. Yi, J. Mei, B.L. Guan, P. Cui, S.H. Luo, Y. Xie, Y.G. Liu, Construction of spherical $\mathrm{NiO} @ \mathrm{MnO}_{2}$ with core-shell structure obtained by depositing $\mathrm{MnO}_{2}$ 
nanoparticles on $\mathrm{NiO}$ nanosheets for high-performance supercapacitor. Ceram. Int. 46, 421-429 (2020).

34. X. Gao, Y. Zhao, K. Dai, J. Wang, B. Zhang, X. Shen, NiCoP nanowire@NiCo-layered double hydroxides nanosheet heterostructure for flexible asymmetric supercapacitors. Chem. Eng. J. 384, 123373 (2020).

35. Z. Ma, F. Jing, Y. Fan, L. Hou, L. Su, L. Fan, G. Shao, High-stability $\mathrm{MnO}_{\mathrm{x}}$ nanowires@C@@ $\mathrm{MnO}_{\mathrm{x}}$ nanosheet core-shell heterostructure pseudocapacitance electrode based on reversible phase transition mechanism. Small 15, 1900862 (2019).

36. J. Yang, C. Yu, X. Fan, J. Qiu, 3D Architecture materials made of NiCoAl-LDH nanoplates coupled with NiCo-carbonate hydroxide nanowires grown on flexible graphite paper for asymmetric supercapacitors. Adv. Energy Mater. 4, 1400761-1400769 (2014).

37. Z. Lu, W. Zhu, X. Lei, G.R. Williams, D. O’Hare, Z. Chang, X. Sun, X. Duan, High pseudocapacitive cobalt carbonate hydroxide films derived from CoAl layered double hydroxides. Nanoscale 4, 3640-3643 (2012).

38. S.C. Sekhar, G. Nagaraju, J.S. Yu, Conductive silver nanowires-fenced carbon cloth fibers-supported layered double hydroxide nanosheets as a flexible and binder-free electrode for high-performance asymmetric supercapacitors. Nano Energy 36, 58-67 (2017).

39. D.D. Wei, Y.L. Zhang, X.Z. Zhu, M.L. Fan, Y.L. Wang, CNT/Co ${ }_{3} \mathrm{~S}_{4} @ \mathrm{NiCo}$ LDH ternary nanocomposites as battery-type electrode materials for hybrid 
supercapacitors. J. Alloy. Compd. 824, 153937 (2019).

40. J. Wang, Q. Zhong, Y.Q. Zeng, D.Y. Cheng, Y.G. Xiong, Y.F. Bu, Rational construction of triangle-like nickel-cobalt bimetallic metal-organic framework nanosheets arrays as battery-type electrodes for hybrid supercapacitors. J. Colloid Interface Sci. 555, 42-52 (2019).

41. H.C. Chen, S.P. Jiang, B.H. Xu, C.H. Huang, Y.Z. Hu, Y.L. Qin, M.X. He, H.J. Cao, Sea-urchin-like nickel-cobalt phosphide/phosphate composites as advanced battery materials for hybrid supercapacitors. J. Mater. Chem. A 7, 6241 (2019).

42. C.X. Zhou, T.T. Gao, Y.J. Wang, Q.L. Liu, D. Xiao, Through a hydrothermal phosphatization method synthesized $\mathrm{NiCo}$ and $\mathrm{Fe}$ based electrodes for high-performance battery-supercapacitor hybrid device. Appl. Surf. Sci. 475, 729-739 (2019).

43. B.B. Cheng, W. Zhang, M. Yang, Y.J. Zhang, F.B. Meng, Preparation and study of porous $\mathrm{MnCo}_{2} \mathrm{O}_{4} @ \mathrm{NiO}$ nanosheets for high-performance supercapacitor. Ceram. Int. 45, 20451-20457 (2019).

44. X.J. Zhang, S.J. Hou, Z.B. Ding, G. Zhu, H.R. Tang, Y.C. Hou, T. Lu, L.K. Pan, Carbon wrapped CoP hollow spheres for high performance hybrid supercapacitor. J. Alloy. Compd. 822, 153578 (2019).

45. H.J. Zhang, X.P. Li, A. Hähnel, V. Naumann, C. Lin, S. Azimi, S.L. Schweizer, A. W. Maijenburg, R. B. Wehrspohn, Bifunctional heterostructure assembly of NiFe LDH nanosheets on NiCoP nanowires for highly efficient and stable overall water splitting. Adv. Funct. Mater. 28, 1706847 (2018). 
46. H.C. Chen, S.P. Jiang, B.H. Xu, C.H. Huang, Y.Z. Hu, Y.L. Qin, M.X. He, H.J. Cao, Sea-urchin-like nickel-cobalt phosphide/phosphate composites as advanced battery materials for hybrid supercapacitors. J. Mater. Chem. A 7, 6241-6249 (2019).

47. Q. Zong, H. Yang, Q.Q. Wang, Q.L. Zhang, Y.L. Zhu, H.Y. Wang, Q.H. Shen, Three-dimensional coral-like NiCoP@C@Ni(OH $)_{2}$ core-shell nanoarrays as battery-type electrodes to enhance cycle stability and energy density for hybrid supercapacitors. Chem. Eng. J. 361, 1-11 (2019).

48. D. Wang, L.B. Kong, M.C. Liu, Y.C. Luo, L. Kang, An approach to preparing Ni-P with different phases for use as supercapacitor electrode materials. Chem. Eur. J. 21, 17897-17903 (2015).

49. X.D. Li, R. Ding, W. Shi, Q.L. Xu, L. Wang, H.X. Jiang, Z. Yang, E.H. Liu, Hierarchical mesoporous Ni-P@ $\mathrm{MnO}_{2}$ composite for high performance supercapacitors. Mater. Lett. 187, 144-147 (2017).

50. Z. Hu, Z.M. Liu, J.G. Zhao, X.Z. Yu, B.A. Lu, Rose-petals-derived hemispherical micropapillae carbon with cuticular folds for super potassium storage. Electrochim. Acta. 368, 137629 (2021).

51. S.S. Zheng, Q. Li, H.G. Xue, H. Pang, Q. Xu, A highly alkaline-stable metal oxide@metal-organic framework composite for high-performance electrochemical energy storage. Natl. Sci. Rev. 7, 305-314 (2020).

52. S.S. Zheng, X.T. Guo, H.G. Xue, K.M. Pan, C.S. Liu, H. Pang, Facile one-pot generation of metal oxide/hydroxide@metal organic framework composites: 
highly efficient bifunctional electrocatalysts for overall water splitting ChemComm. 55, 10904-10907 (2019).

53. X. Wang, Y. Fang, B. Shi, F. Huang, F. Rong, R. Que, Three-dimensional $\mathrm{NiCo}_{2} \mathrm{O}_{4} @ \mathrm{NiCo}_{2} \mathrm{O}_{4}$ core-shell nanocones arrays for high-performance supercapacitors. Chem. Eng. J. 344, 311-319 (2018).

54. Y.Y. Lan, H.Y. Zhao, Y. Zong, X.H. Li, Y. Sun, J. Feng, Y. Wang, X.L. Zheng, Y.P. $\mathrm{Du}$, Phosphorization boosts the capacitance of mixed metal nanosheet arrays for high performance supercapacitor electrodes. Nanoscale 10, 11775-11781 (2018).

55. N. Feng, R.J. Meng, L.H. Zu, Y.T. Feng, C.X. Peng, J.M. Huang, G.L. Liu, B.J. Chen, J.H. Yang, A polymer-direct-intercalation strategy for $\mathrm{MoS}_{2} /$ carbon-derived heteroaerogels with ultrahigh pseudocapacitance. Nat. Commun. 10, 1372 (2019).

56. H.B. Ding, J. Zhou, A.M. Rao, B.A. Lu, Cell-like-carbon-micro-spheres for robust potassium anode. Natl. Sci. Rev. nwaa276, DOI: 10.1093/nsr/nwaa276 (2020).

57. K. Zhou, W.J. Zhou, L.J. Yang, J. Lu, S. Cheng, W.J. Mai, Z.H. Tang, L.G. Li, S.W. Chen, Ultrahigh-performance pseudocapacitor electrodes based on transition metal phosphide nanosheets array via phosphorization: a general and effective approach. Adv. Funct. Mater. 25, 7530-7538 (2015).

\section{Figure captions}

Fig. 1 Schematic illustration for the formation mechanism of flexible hierarchical 
$1 \quad \mathrm{Ni}_{2} \mathrm{P} @ \mathrm{Ni}(\mathrm{OH})_{2} @ \mathrm{CC}$ electrode

2 Fig. 2 a Optical photographs of $\mathrm{CC}$ substrate, $\mathrm{Ni}(\mathrm{OH})_{2} @ \mathrm{CC}, \mathrm{Ni}_{2} \mathrm{P} @ \mathrm{CC}$ and

$3 \mathrm{Ni}_{2} \mathrm{P} @ \mathrm{Ni}(\mathrm{OH})_{2} @ \mathrm{CC} . \quad$ b Optical photograph shows the flexibility of

$4 \quad \mathrm{Ni}_{2} \mathrm{P} @ \mathrm{Ni}(\mathrm{OH})_{2} @ \mathrm{CC}$ electrode. c $\quad$ Representative $\mathrm{SEM}$ images of

$5 \quad \mathrm{Ni}_{2} \mathrm{P} @ \mathrm{Ni}(\mathrm{OH})_{2} @ \mathrm{CC}$. Inset shows the magnifying image of $\mathrm{Ni}_{2} \mathrm{P} @ \mathrm{Ni}(\mathrm{OH})_{2}$ nanosheet

6 arrays on $\mathrm{CC}$ substrate. d EDS elemental mappings of $\mathrm{Ni}, \mathrm{P}$ and $\mathrm{O}$ in

$7 \mathrm{Ni}_{2} \mathrm{P} @ \mathrm{Ni}(\mathrm{OH})_{2} @ \mathrm{CC}$. e TEM and f HRTEM images of $\mathrm{Ni}_{2} \mathrm{P} @ \mathrm{Ni}(\mathrm{OH})_{2}$ nanosheets

8 scraped off from the CC substrate

9 Fig. 3 XPS spectra of a Ni 2p and b P 2p for $\mathrm{Ni}_{2} \mathrm{P} @ \mathrm{CC}$ and $\mathrm{Ni}_{2} \mathrm{P} @ \mathrm{Ni}(\mathrm{OH})_{2} @ \mathrm{CC}$

Fig.4 a CV curves of $\mathrm{Ni}_{2} \mathrm{P} @ \mathrm{CC}$ and $\mathrm{Ni}_{2} \mathrm{P} @ \mathrm{Ni}(\mathrm{OH})_{2} @ \mathrm{CC}$ electrodes at $5 \mathrm{mV} \mathrm{s}^{-1}$. b

11 GCD curves of $\mathrm{Ni}_{2} \mathrm{P} @ \mathrm{CC}$ and $\mathrm{Ni}_{2} \mathrm{P} @ \mathrm{Ni}(\mathrm{OH})_{2} @ \mathrm{CC}$ electrodes at $1 \mathrm{~mA} \mathrm{~cm}{ }^{-2} \cdot \mathbf{c} \mathrm{CV}$

12 curves of $\mathrm{Ni}_{2} \mathrm{P} @ \mathrm{Ni}(\mathrm{OH})_{2} @ \mathrm{CC}$ electrode at different scan rates. d GCD curves of

$13 \mathrm{Ni}_{2} \mathrm{P} @ \mathrm{Ni}(\mathrm{OH})_{2} @ \mathrm{CC}$ electrodes at different current densities. e Areal capacitances

14 and gravimetric capacitances of $\mathrm{Ni}_{2} \mathrm{P} @ \mathrm{CC}$ and $\mathrm{Ni}_{2} \mathrm{P} @ \mathrm{Ni}(\mathrm{OH})_{2} @ \mathrm{CC}$ electrodes at

15 various current densities. f EIS of $\mathrm{Ni}_{2} \mathrm{P} @ \mathrm{CC}$ and $\mathrm{Ni}_{2} \mathrm{P} @ \mathrm{Ni}(\mathrm{OH})_{2} @ \mathrm{CC}$ electrodes.

16 Inset is a view of the high-frequency region

17 Fig. 5 Relationship between logarithm anodic peak currents and logarithm scan rates

18 Fig.6 Cycling stabilities of $\mathrm{Ni}_{2} \mathrm{P} @ \mathrm{CC}$ and $\mathrm{Ni}_{2} \mathrm{P} @ \mathrm{Ni}(\mathrm{OH})_{2} @ \mathrm{CC}$ at a current density of

$192 \mathrm{~mA} \mathrm{~cm}^{-2}$

Fig. $7 \mathrm{Ni}_{2} \mathrm{P} @ \mathrm{Ni}(\mathrm{OH})_{2} @ \mathrm{CC} / / \mathrm{AC}$ hybrid supercapacitors: a CV curves at different scan

rates. b GCD curves at different current densities. c The specific capacitances at

different current densities. d Ragone plots of power density and energy density. e 
1 Cycling stability at $5 \mathrm{~mA} \mathrm{~cm}^{-2}$ for 5000 cycles. 


\section{Figures}

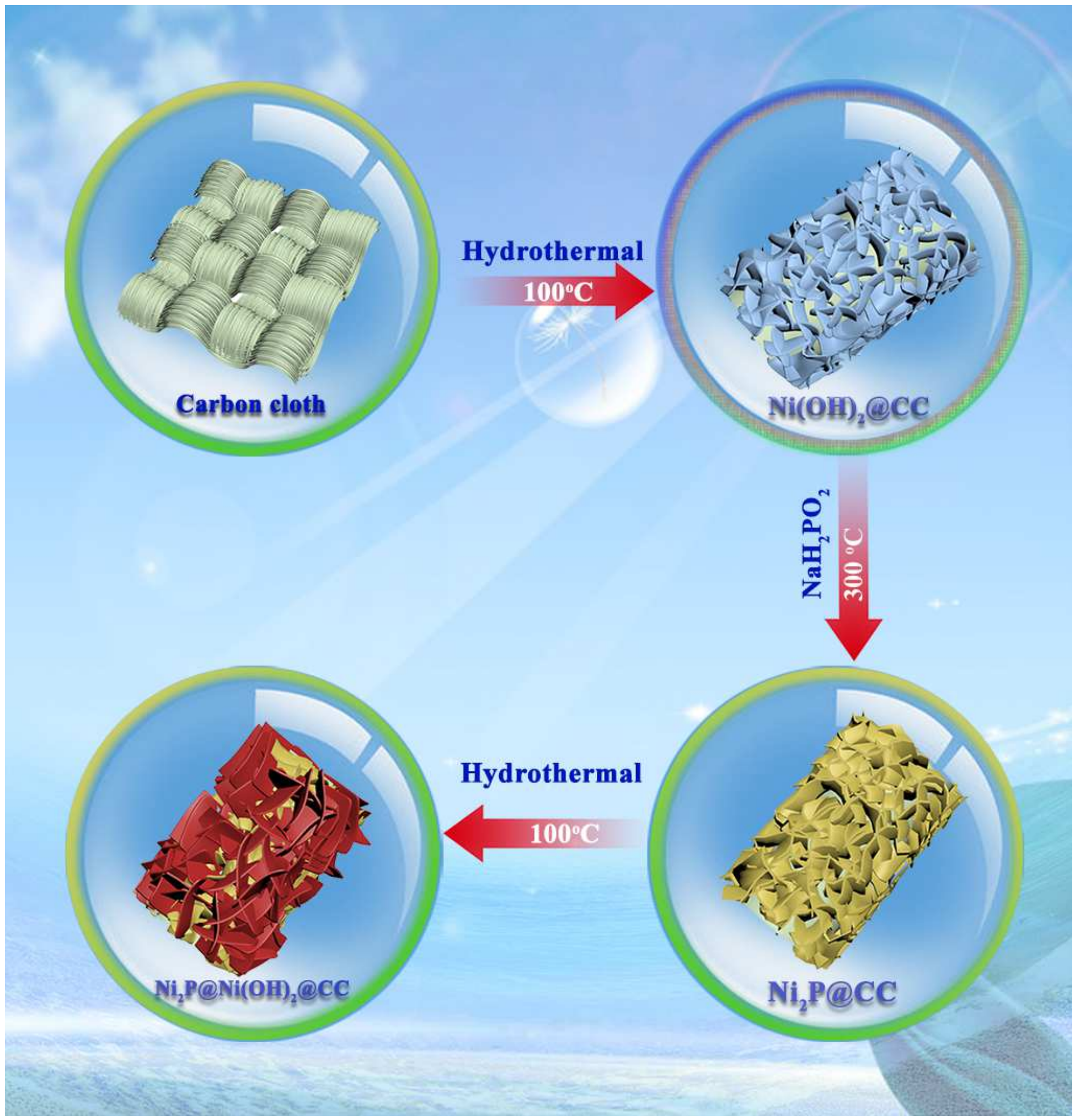

\section{Figure 1}

Schematic illustration for the formation mechanism of flexible hierarchical Ni2P@Ni(OH)2@CC electrode 


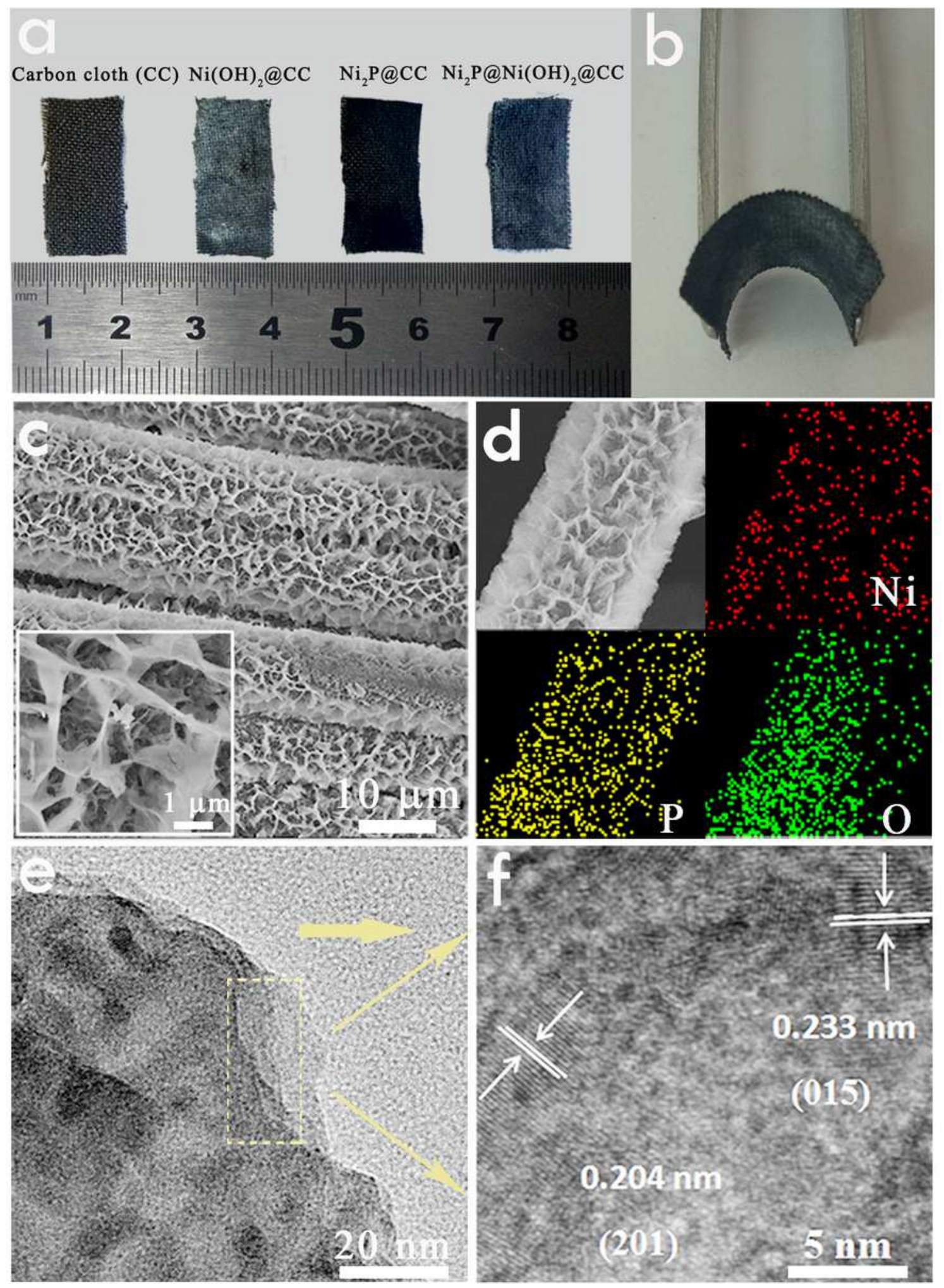

Figure 2

a Optical photographs of CC substrate, Ni(OH)2@CC, Ni2P@CC and Ni2P@Ni(OH)2@CC. b Optical photograph shows the flexibility of Ni2P@Ni(OH)2@CC electrode. c Representative SEM images of Ni2P@Ni(OH)2@CC. Inset shows the magnifying image of Ni2P@Ni(OH)2 nanosheet arrays on CC substrate. d EDS elemental mappings of Ni, P and 0 in Ni2P@Ni(OH)2@CC.e TEM and f HRTEM images of Ni2P@Ni(OH)2 nanosheets scraped off from the CC substrate 

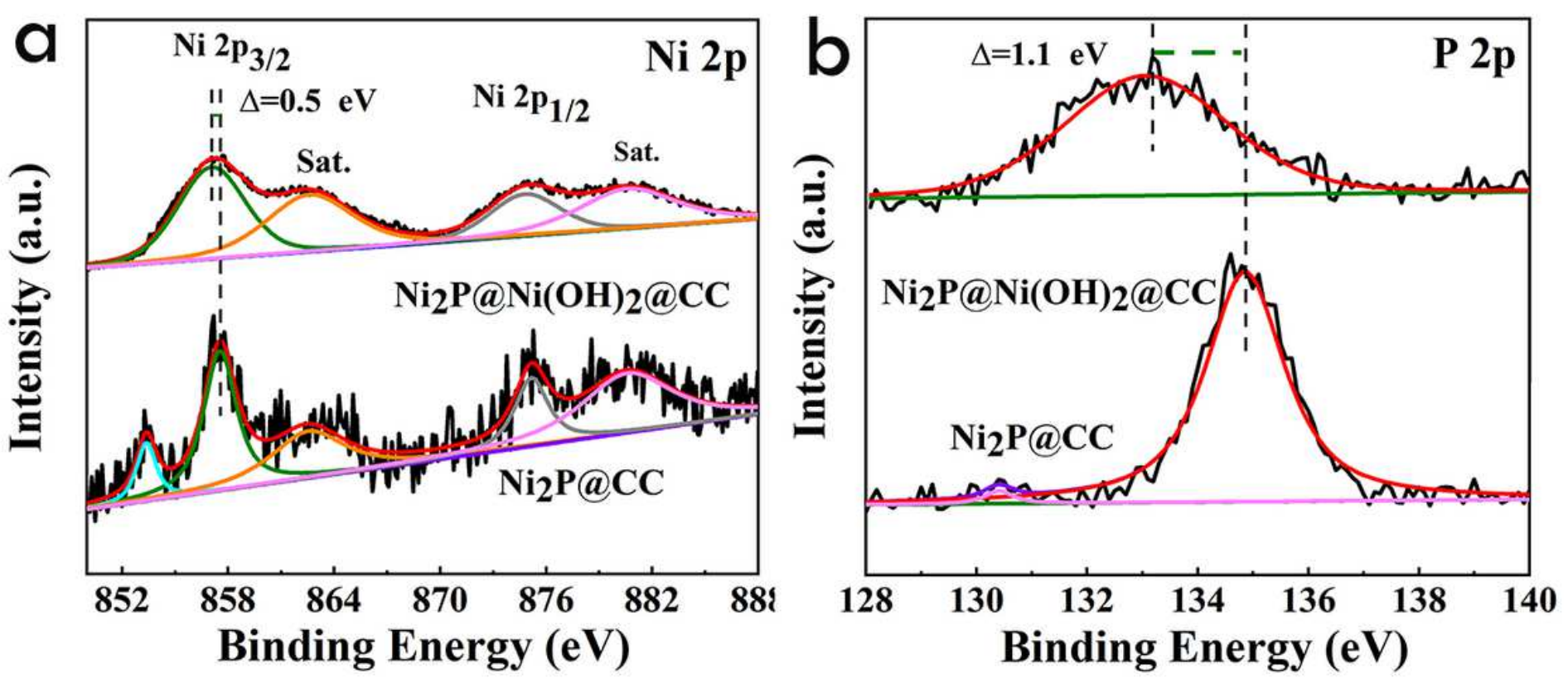

Figure 3

XPS spectra of a Ni 2p and b P 2p for Ni2P@CC and Ni2P@Ni(OH)2@CC 

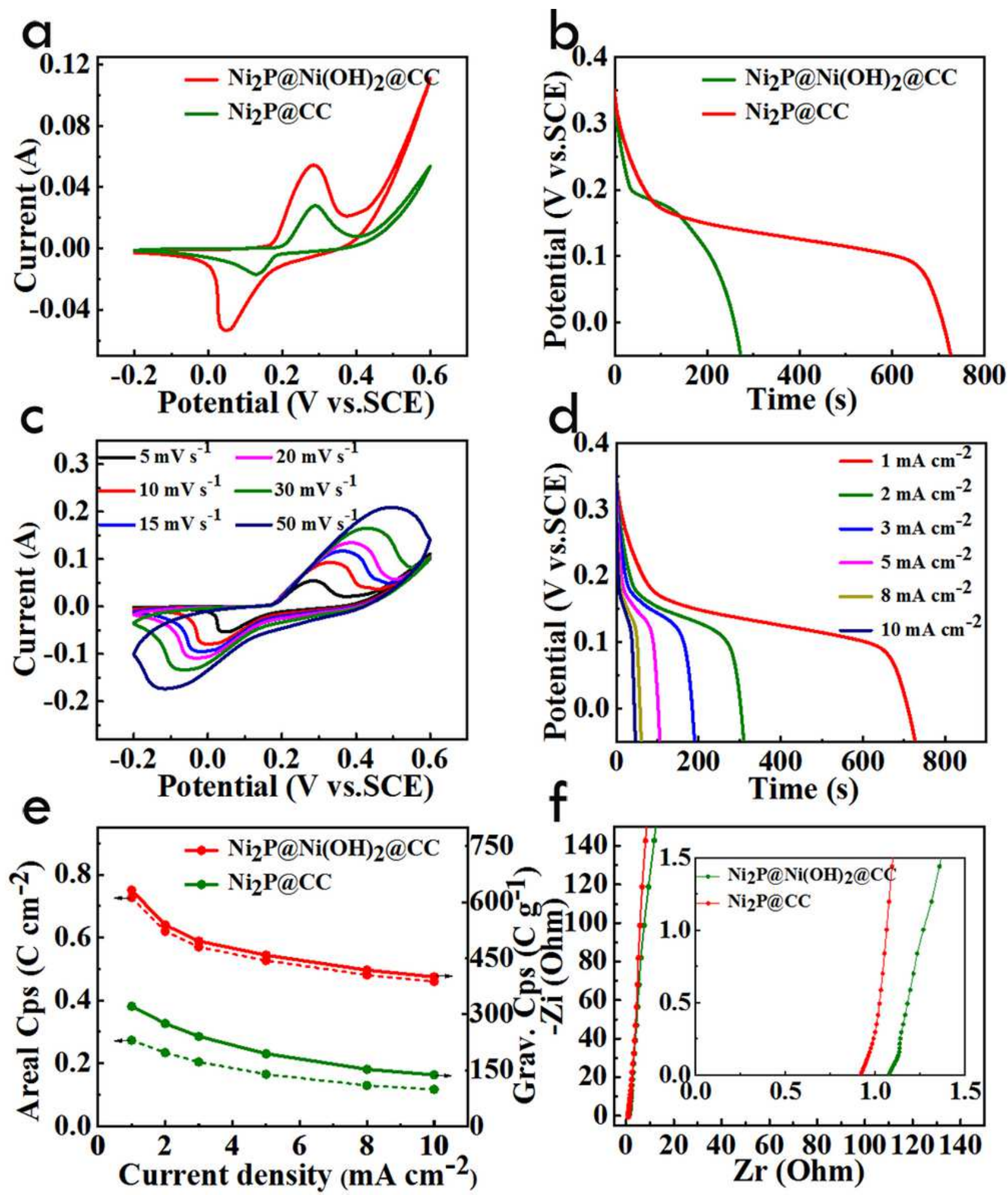

Figure 4

a CV curves of Ni2P@CC and Ni2P@Ni(OH)2@CC electrodes at 5 mV s-1. b GCD curves of Ni2P@CC and Ni2P@Ni(OH)2@CC electrodes at 1 mA cm-2. c CV curves of Ni2P@Ni(OH)2@CC electrode at different scan rates. d GCD curves of Ni2P@Ni(OH)2@CC electrodes at different current densities. e Areal capacitances and gravimetric capacitances of Ni2P@CC and Ni2P@Ni(OH)2@CC electrodes at various 
current densities. f EIS of Ni2P@CC and Ni2P@Ni(OH)2@CC electrodes. Inset is a view of the highfrequency region

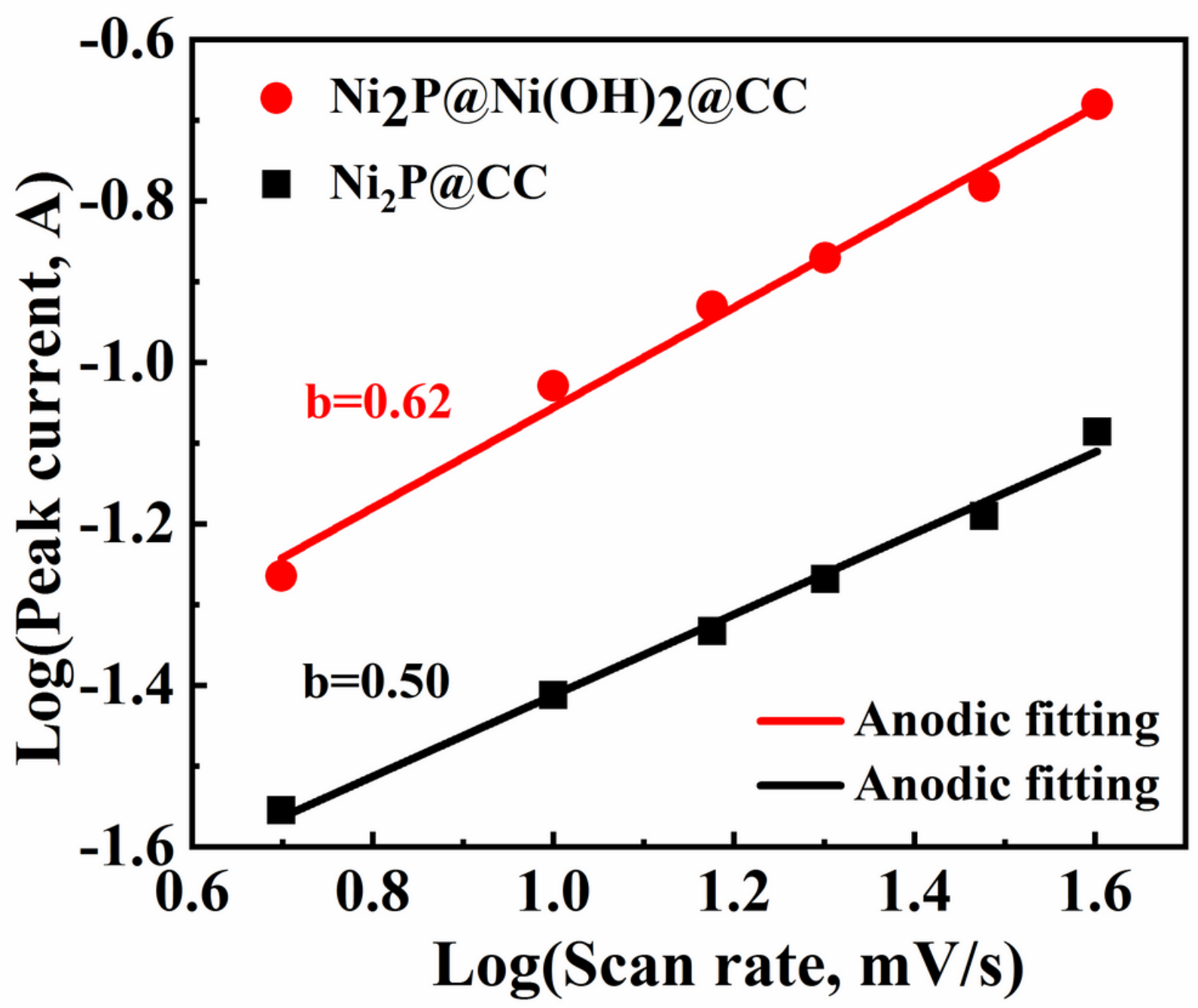

Figure 5

Relationship between logarithm anodic peak currents and logarithm scan rates 


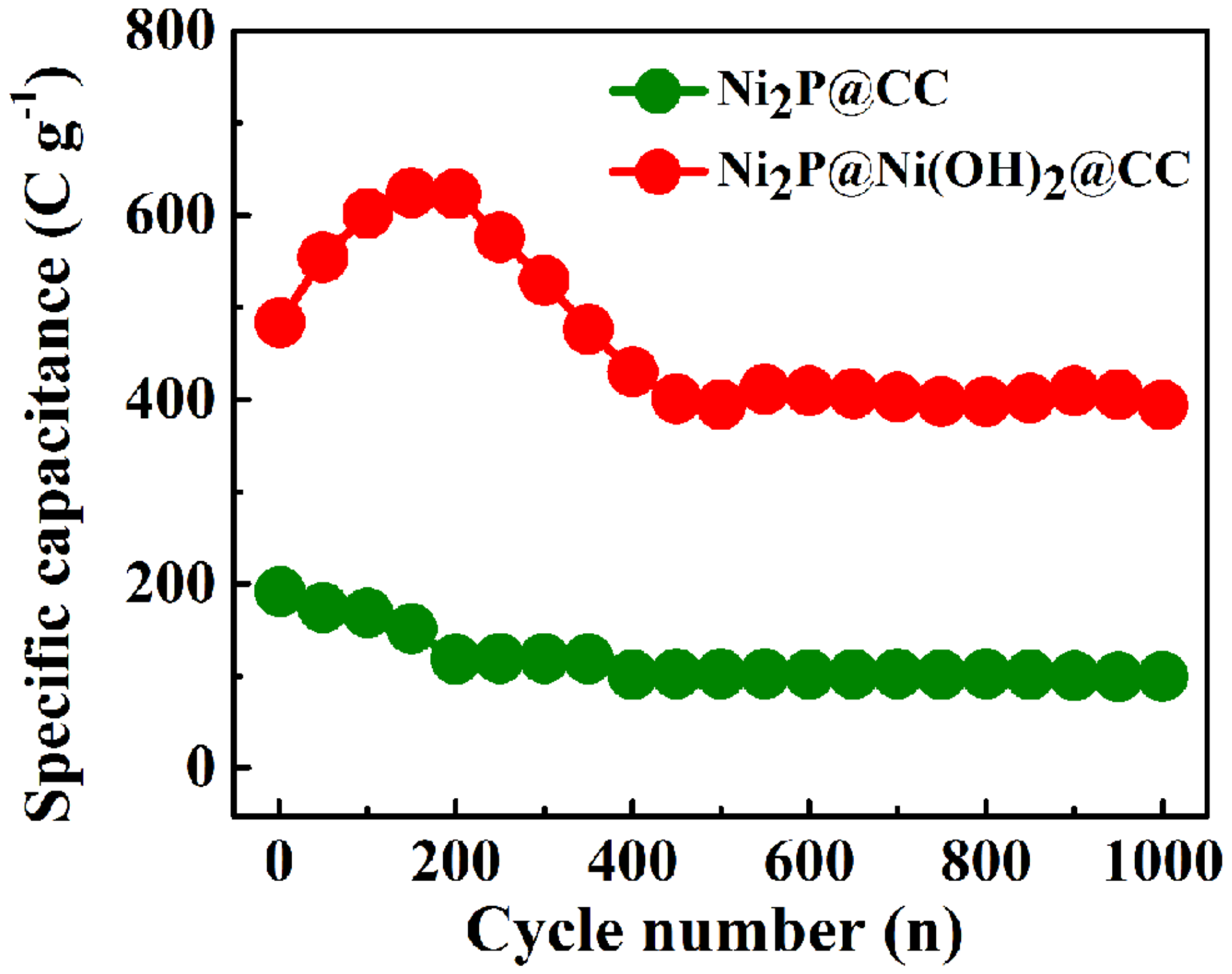

Figure 6

Cycling stabilities of Ni2P@CC and Ni2P@Ni(OH)2@CC at a current density of 2 mA cm-2 
a
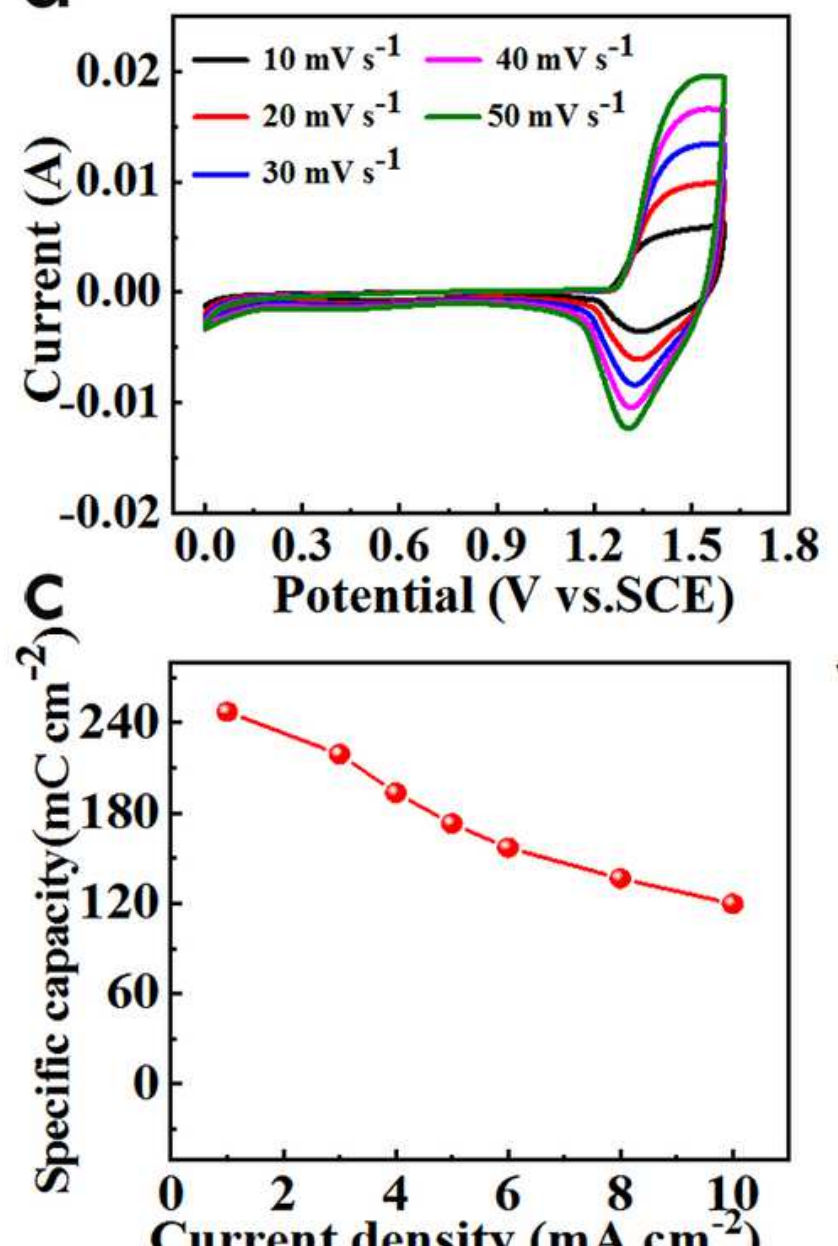

Current density $\left(\mathrm{mA} \mathrm{cm}^{-2}\right)$ b
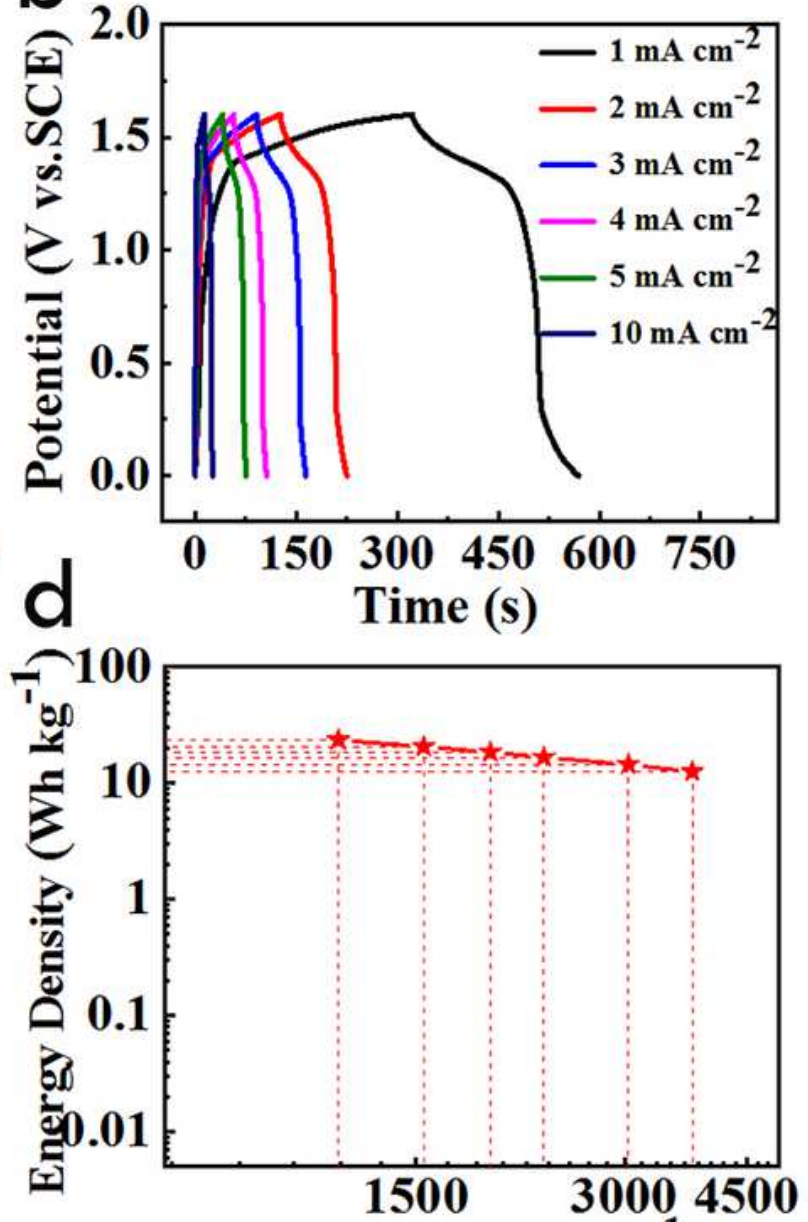

Power density $\left(\mathrm{W} \mathrm{kg}^{-1}\right)$

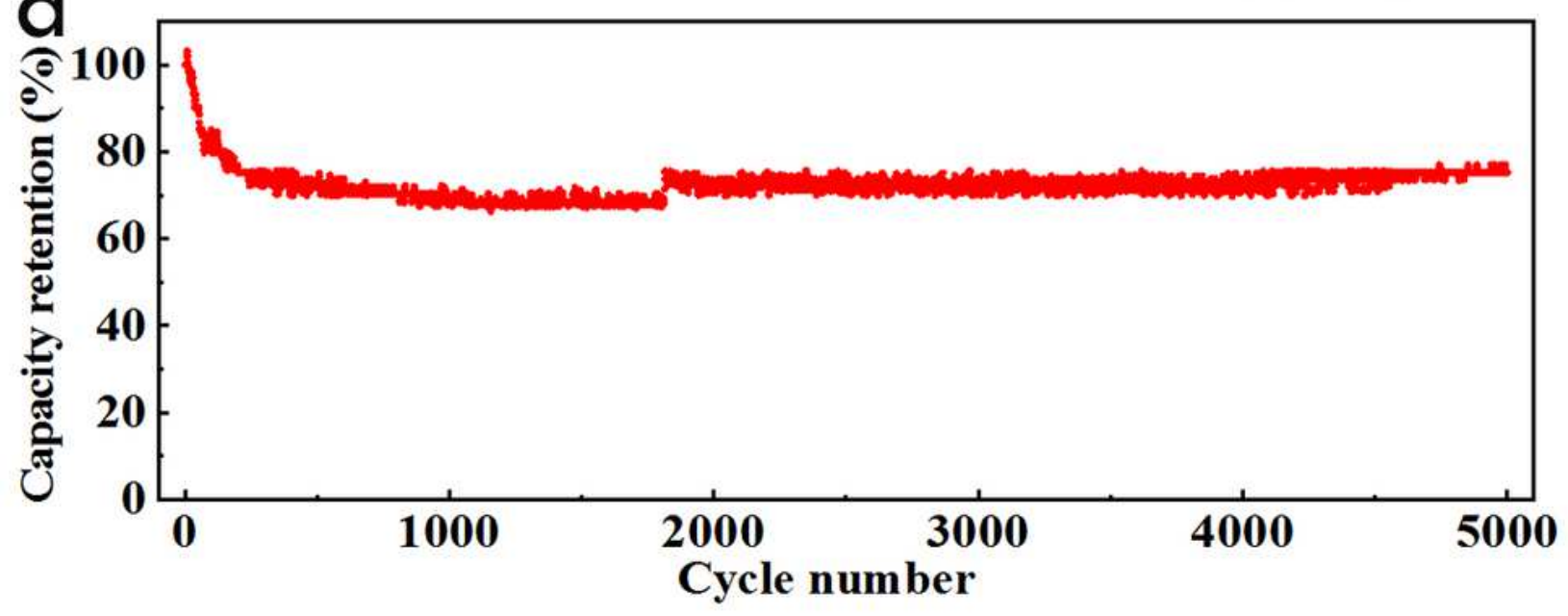

Figure 7

Ni2P@Ni(OH)2@CC//AC hybrid supercapacitors: a CV curves at different scan rates. b GCD curves at different current densities. c The specific capacitances at different current densities. d Ragone plots of power density and energy density. e Cycling stability at $5 \mathrm{~mA} \mathrm{~cm}-2$ for 5000 cycles.

\section{Supplementary Files}


This is a list of supplementary files associated with this preprint. Click to download.

- SupplementaryMaterial.doc 